\title{
Parenteral Administration of Glutamine Modulates Acute Phase Response in Postparturient Dairy Cows
}

\author{
A. Jafari, ${ }^{\star 1}$ D. G. V. Emmanuel,, ${ }^{*}$ R. J. Christopherson, ${ }^{*}$ J. R. Thompson,† G. K. Murdoch, ${ }^{*}$ \\ J. Woodward, ${ }^{\star}$ C. J. Field, ${ }^{*}$ and B. N. Ametaj ${ }^{\star 2}$ \\ *Department of Agricultural, Food and Nutritional Science, University of Alberta, Edmonton, Canada T6G 2P5 \\ †Faculty of Land and Food Systems, University of British Columbia, Vancouver, Canada V6T 1Z1
}

\begin{abstract}
The objective of this study was to investigate whether administration of L-Gln would affect mediators of acute phase response in postparturient dairy cows. Twentyfour multiparous Holstein cows were blocked by the expected day of calving and randomly assigned to 1 of the 3 treatment groups ( $n=8$ /group): 1 ) i.v. infusion of $10 \mathrm{~L}$ of $0.85 \% \mathrm{NaCl}$ (control), 2) i.v. infusion of 106 , or 3) $212 \mathrm{~g} / \mathrm{d}$ of L-Gln mixed with $10 \mathrm{~L}$ of $0.85 \% \mathrm{NaCl}$ solution; each treatment was given $8 \mathrm{~h} / \mathrm{d}$ for each of 7 consecutive days starting on d 1 after calving. Blood samples were collected $1 \mathrm{wk}$ before the expected day of parturition as well as on d $0,7,14$, and 21 after parturition; plasma concentrations of serum amyloid A (SAA), haptoglobin, and lipopolysaccharide-binding protein were measured by ELISA, and $\alpha_{1}$-acid glycoprotein was assessed by radial immunodiffusion. Concentrations of SAA, haptoglobin, and $\alpha_{1}$-acid glycoprotein increased in control cows after parturition, reaching peak values on $\mathrm{d} 0$ or 7 postpartum $(60,1,093$, and $963 \mu \mathrm{g} / \mathrm{mL}$, respectively). Cows infused with $106 \mathrm{~g} / \mathrm{d}$ of L-Gln had greater concentrations of SAA in plasma on $d 14$ and 21 compared with controls (62.8 vs. 30.2 and 71.1 vs. $34.5 \mu \mathrm{g} / \mathrm{mL}$, respectively). Cows infused with $212 \mathrm{~g} / \mathrm{d}$ of L-Gln had greater concentrations of SAA on d 7 (82.5 vs. $53.9 \mu \mathrm{g} / \mathrm{mL}$ ) and lower concentrations of haptoglobin on d 14 and 21 postpartum compared with controls (264 vs. 621 and 175 vs. $587 \mu \mathrm{g} / \mathrm{mL}$, respectively). Cows treated with 106 and $212 \mathrm{~g} / \mathrm{d}$ of L-Gln had greater plasma lipopolysaccharide-binding protein concentrations on 7 compared with control group (50.0 and 35.6 vs. $10.8 \mu \mathrm{g} / \mathrm{mL}$, respectively). There were no treatment differences with respect to milk yield and DM intake during the experimental period. In conclusion, our data indicate that i.v. administration of L-Gln modulated acute phase mediators in dairy cows after parturition
\end{abstract}

\footnotetext{
Received March 9, 2006.

Accepted July 24, 2006.

${ }^{1}$ Present address: Isfahan University of Technology, Isfahan, Iran 84156.

${ }^{2}$ Corresponding author: burim.ametaj@ualberta.ca
}

and warrants further research into the mechanisms behind these effects.

Key words: dairy cow, L-glutamine, acute phase protein

\section{INTRODUCTION}

Initiation of lactation imposes a great metabolic challenge on dairy cows in terms of both protein and energy demands. In high yielding dairy cows, for example, more than $1 \mathrm{~kg}$ of milk protein is secreted daily, equivalent to more than $30 \%$ of plasma protein flux (Bequette et al., 1996). Glutamine is the most abundant amino acid in the plasma and milk, and during early lactation a decline of 25 to $33 \%$ was reported for the concentration of free Gln in the plasma of dairy cows (Meijer et al., 1993). Although Gln is a nonessential amino acid, based on requirements for milk protein synthesis, it has been hypothesized that Gln deficiency might limit milk protein production (Meijer et al., 1993).

The transition period is characterized by a high incidence of inflammatory conditions and activation of a general nonspecific immune response known as the acute phase response (Ametaj et al., 2005). The stimuli for activation of acute phase response around parturition are not well understood; however, subacute mammary infections pre- and postpartum, uterine infections, and feeding of dairy cows high-grain diets immediately after parturition are associated with the release of large amounts of endotoxin and its translocation into the bloodstream (Mateus et al., 2003). Inflammatory conditions are accompanied by a large increase in Gln uptake by the liver. The augmented uptake of Gln by hepatic cells is needed to support synthesis of acute phase proteins, gluconeogenesis, and glutathione biosynthesis.

The major endogenous supplier of Gln is skeletal muscle; however, during high milk production and the presence of inflammatory conditions, the free pool of Gln in the muscle cells declines by $75 \%$ (Palmer et al., 1996). As a result, when the endogenous supply cannot match the increased demand for Gln, a conditional deficiency may develop (Plumley et al., 1990). In these 
situations, the administration of exogenous Gln may be beneficial.

Although Gln is suggested to support synthesis of proteins in the liver, there is a lack of information on its role in modulation of acute phase proteins in dairy cows. Four intensively studied acute phase proteins in dairy cows are serum amyloid A (SAA), haptoglobin, LPS-binding protein (LBP), and $\alpha_{1}$-acid glycoprotein $\left(\alpha_{1}\right.$-AGP). Serum amyloid A is associated with highdensity lipoproteins (HDL) and is involved in the detoxification of plasma toxins (Baumberger et al., 1991). Haptoglobin binds hemoglobin and prevents the utilization of iron by bacteria (Wassell, 2000). Lipopolysaccharide-binding protein facilitates binding of endotoxin to macrophages and neutralization of endotoxin by HDL (Wurfel et al., 1995), whereas $\alpha_{1}$-AGP is an antiinflammatory agent that controls inappropriate or extended activation of immune system (Moore et al., 1997).

The acute phase response has been studied in various inflammatory and disease states in periparturient cattle; however, no studies have investigated the modulatory effects of Gln on acute phase proteins in dairy cows. We hypothesized that i.v. administration of Gln in the postpartum cows might modulate mediators of acute phase response. Therefore, the objective of this study was to investigate the effects of parenteral administration of 2 different doses of Gln on mediators of acute phase response in postparturient dairy cows.

\section{MATERIALS AND METHODS}

\section{Animals and Treatments}

Twenty-four pregnant multiparous Holstein cows were blocked based on parity, previous milk production, and expected day of calving and were randomly assigned to 1 of 3 treatment groups (8/group) in a randomized block design $1 \mathrm{wk}$ before the expected day of calving to $21 \mathrm{~d}$ postpartum. Cows were housed in a tie-stall barn with wood shavings for bedding and offered nonlactating and early-lactation diets formulated according to NRC recommendations (2001) for transition dairy cows (Table 1). Diets were mixed and offered as TMR individually once daily at $0700 \mathrm{~h}$. Orts were recorded and discarded before the next feeding each day and the amount of feed was adjusted to ensure a $10 \%$ feed residual. Feed samples were analyzed weekly. Cows were milked twice daily at 0400 and $1500 \mathrm{~h}$, and milk yield was recorded electronically every day for the first $21 \mathrm{~d}$ of lactation. Cows in the experiment showed no clinical signs of infectious or inflammatory diseases. The experiment was conducted at the University of Alberta Dairy Research and Technology Centre, Edmonton, Canada. All cows were managed and treated in
Table 1. Diet composition and nutrients supplied by prepartum and postpartum $\operatorname{diets}^{1}$ (\% DM basis)

\begin{tabular}{lcc}
\hline Item & Prepartum & Postpartum \\
\hline Barley, steam rolled & 16.41 & 29.78 \\
Corn, steam rolled & 4.00 & 7.94 \\
Grass hay & 10.00 & - \\
Alfalfa hay & - & 9.61 \\
Alfalfa silage & - & 19.86 \\
Barley silage & 60.23 & 20.31 \\
Dairy supplement $^{2}$ & 1.09 & 12.50 \\
Animate & 4.84 & - \\
Molasses, beet sugar & 0.55 & - \\
Vegetable oil & 0.70 & - \\
Limestone & 1.56 & - \\
Vitamin E ${ }^{4}$ & 0.39 & - \\
Vitamin ${ }_{3}{ }^{5}$ & 0.23 & - \\
Energy and nutrient composition & & \\
DM & 43.67 & 54.04 \\
NE ${ }_{L}{ }^{6}{ }^{M}$ Mcal/kg & 1.55 & 1.71 \\
NDF & 45.31 & 27.82 \\
ADF & 26.70 & 15.71 \\
NFC & 30.30 & 42.19 \\
Crude fat & 3.70 & 4.61 \\
CP & 14.71 & 18.13 \\
Ca & 0.94 & 1.11 \\
P & 0.40 & 0.50 \\
K & 1.88 & 1.48 \\
Mg & 0.40 & 0.39 \\
\hline
\end{tabular}

${ }^{1}$ Supplied by Champion Feed Services Ltd., Barrhead, AB, Canada.

${ }^{2}$ Contained malt sprouts $(0.1 \%)$, canola fines $(12.47 \%)$, canola meal $(6.0 \%)$, corn gluten $(25.0 \%)$, fish herring meal $(10.0 \%)$, peas, ground $(4.0 \%)$, soybean meal $(10.0 \%)$, canola oil or soy oil $(3.0 \%)$, canola oil (3.0\%), Megalac (7.5\%), calcium carbonate (1.5\%), $\mathrm{MgO} 58 \%(1.6 \%)$, dicalcium phosphate $(5.2 \%)$, salt potash $(3.1 \%)$, sodium bicarbonate (5.0\%), vitamin E 500 (0.03\%), and Champion Feed Services dairy premix $(1.6 \%)$

${ }^{3}$ Anionic mineral supplemented for nonlactating dairy cows, contained CP (minimum, 35.0\%), equivalent CP from nonprotein sources (maximum, 25\%), Ca (actual, 1.10\%), $\mathrm{Mg}$ (actual, 3.65\%), S (actual, $4.65 \%), \mathrm{Cl}$ (actual, 11.90\%), and $(\mathrm{Na}+\mathrm{K})-(\mathrm{Cl}+\mathrm{S})=-6,047 \mathrm{mEq} /$ $\mathrm{kg}$.

${ }^{4}$ Contained 5,000 IU/kg.

${ }^{5}$ Contained 500,000 IU/kg.

${ }^{6}$ Based on weighted averages values provided by Champion Feed Services Ltd. and calculated according to NRC (2001).

${ }^{7} \mathrm{NFC}$ was calculated as: $100-[(\mathrm{NDF}-\mathrm{NDF} \mathrm{CP})+\mathrm{CP}+$ ether extract + Ash] (NRC, 2001).

accordance with the guidelines established by the Canadian Council on Animal Care (1993) and all animalrelated procedures were approved by the University of Alberta Faculty Animal Policy and Welfare Committee.

Cows were infused using i.v. catheters (Jorgensen Laboratories, Inc., Loveland, CO) with $10 \mathrm{~L}$ of $0.85 \%$ $\mathrm{NaCl}$ (control) or with 106 or $212 \mathrm{~g} / \mathrm{d}$ of L-Gln (a gift from Ajinomoto Co., Inc., Tokyo, Japan) dissolved in 10 $\mathrm{L}$ of $0.85 \% \mathrm{NaCl}$ for $8 \mathrm{~h} / \mathrm{d}$ for each of 7 consecutive days starting on $\mathrm{d} 1$ after calving. The average BW for cows after parturition was $664 \pm 39 \mathrm{~kg}$. The 2 doses of L-Gln for cows were calculated from published data on i.v. infusion rates for sheep (Hoskin et al., 2001) and ad- 
justed on the basis of metabolic BW to the level shown above.

The L-Gln was dissolved in isotonic $(0.85 \%) \mathrm{NaCl}$ in double-distilled and pyrogen-free water, filter-sterilized through a microfilter (pore size, $0.22 \mu \mathrm{m}$ ), and then stored in sterile containers. Solutions of L-Gln were prepared once every $4 \mathrm{~d}$ and kept refrigerated prior to use; the solutions were stable during this period (G. E. Lobley, Rowett Research Inst., Aberdeen, UK; personal communication). On the day of parturition, cows were equipped with indwelling jugular venous catheters and maintained for $7 \mathrm{~d}$. At least once daily, the jugular veins were examined for inflammatory reactions, and catheters were flushed with approximately $15 \mathrm{~mL}$ of $0.85 \%$ sterile saline. Catheters were filled with 2 to 3 $\mathrm{mL}$ of $0.85 \%$ sterile saline containing $50 \mathrm{IU}$ of heparin (Sigma-Aldrich Canada Ltd., Oakville, ON, Canada) to prevent clot formation.

\section{Blood Sampling and Laboratory Analyses}

Blood samples were obtained 3 to $4 \mathrm{~h}$ after the morning feeding from the tail vein on $\mathrm{d} 7$ before the expected day of calving, on the day of calving, and on d 7, 14, and 21 after calving. Vacutainer tubes containing $\mathrm{K}_{2^{-}}$ EDTA (Fisher Scientific, Nepean, ON, Canada) were used for blood collection. Samples were centrifuged within 20 min and plasma was collected, immediately placed on ice, transported to the laboratory, and frozen at $-20^{\circ} \mathrm{C}$ until analysis.

SAA. Serum amyloid A was measured with a commercially available bovine sandwich ELISA kit (Tridelta Development Ltd., Greystones, Ireland) according to the manufacturer's instructions. All samples including the standards were tested in duplicate. Samples were initially diluted 1:500. Optical density values were read on an automatic plate reader (model Spectra Max 190; Molecular Devices, Sunnyvale, CA) at $450 \mathrm{~nm}$ with reference at $630 \mathrm{~nm}$. According to the manufacturer, the detection limit of the assay was $0.3 \mu \mathrm{g} / \mathrm{mL}$.

Haptoglobin. Concentrations of haptoglobin in plasma were quantified in duplicate by means of a bovine sandwich ELISA kit (Tridelta Development Ltd.). The bovine serum standard was calibrated against a standard obtained from a European Union concerted action on standardization of animal acute phase proteins (QLK5-CT-1999-01532). The lower detection limit of the assay, as defined by the linear range of the standard curve, was $0.5 \mu \mathrm{g} / \mathrm{mL}$. The samples were tested in dilutions of 1:100. The optical density at $630 \mathrm{~nm}$ was measured on a microplate reader (Molecular Devices).

$\boldsymbol{L B P}$. Plasma LBP was determined with a commercially available LBP ELISA kit that crossreacts with bovine LBP (Cell Sciences, Inc., Norwood, MA). Plasma samples were initially diluted 1:1,500; samples with optical density values lower than the range of the standard curve were diluted 1:1,200 and reassayed according to the manufacturer's instructions. The optical density at $450 \mathrm{~nm}$ and a correction wavelength of 550 $\mathrm{nm}$ were measured on a microplate reader (Molecular Devices).

$\alpha_{1}$-AGP. Concentrations of $\alpha_{1}$-AGP in plasma were measured with bovine radial immunodiffusion assay plates (Tridelta Development Ltd.). Single radial immunodiffusion assays were prepared to measure plasma concentrations of $\alpha_{1}$-AGP. Calibrators and samples were applied to wells in $5-\mu \mathrm{L}$ volumes. Plates were placed in humidified chambers at $37^{\circ} \mathrm{C}$ and allowed to incubate for $24 \mathrm{~h}$ before reading test results. For the calibrators, a plot of the diameter squared on the $y$-axis and the concentration of the antigen on the $x$-axis gave a linear function as described previously by Mancini et al. (1965). Sample concentrations were calculated on the basis of this linear function.

\section{Statistical Analyses}

The experiment was a randomized block design based upon expected calving date. Data were analyzed as a repeated measure study by using the MIXED model procedure of SAS (Version 9.1, SAS Institute, 2002). For variables measured over time, the model included treatment, time, and 2-way interactions as fixed effect, and time was the repeated effect. If interaction was not significant, it was excluded in the model for further analysis. Akaike's information criterion (Wang and Goonewardene, 2004) was used as a fit statistic to determine the most appropriate covariance structure in the final model for each dependent variable. Simple covariance structure fitted the best for all variables. Prepartum values for all measurements were used as covariables during the analysis. The method of KenwardRoger was used for calculation of denominator degrees of freedom for $F$-test. Mean differences for all variables were separated and compared using Tukey's multiple comparison procedure. Data in the text and graphs are presented as least squares means \pm SEM $(\mathrm{n}=8) ; P$ values $<0.05$ were considered significant.

\section{RESULTS}

There were no significant differences in milk production or dietary intake among the 3 treatment groups during the entire experimental period (Figures 1 and 2 , respectively). There were significant time effects as both milk yield and DMI increased $(P<0.001)$ as lactation advanced. A treatment $(P=0.003)$, time $(P<0.001)$, and time by treatment interaction $(P<0.001)$ were 


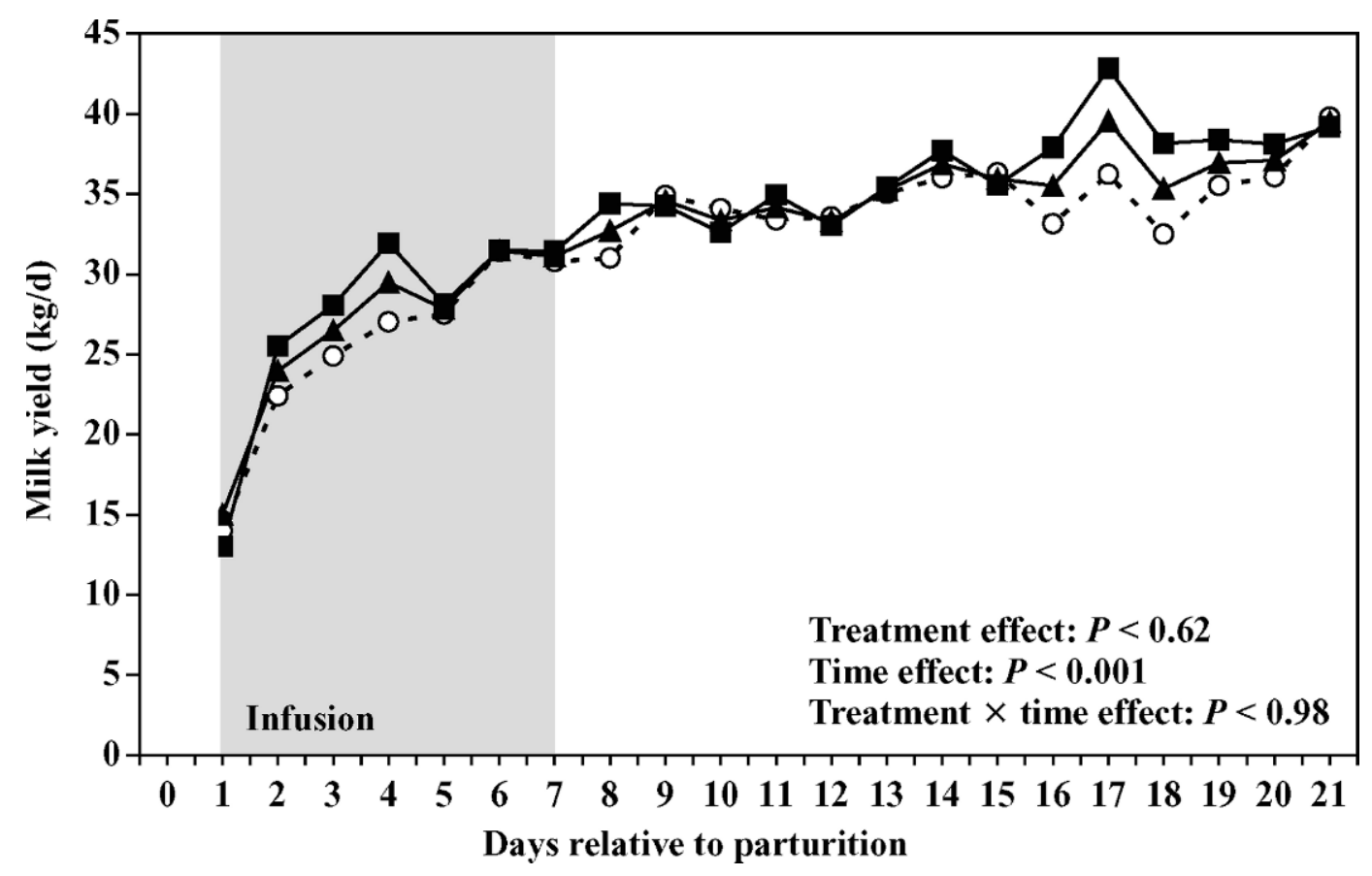

Figure 1. Least squares means of daily milk yield ( $\mathrm{kg} / \mathrm{d})$ in Holstein dairy cows ( $\mathrm{n}=8$ each group) infused i.v. for $8 \mathrm{~h}$ during $\mathrm{d} 1$ to 7 postpartum with either $10 \mathrm{~L}$ of saline $(0.85 \mathrm{~g} / \mathrm{L}$ of NaCl; control; O) or $106 \mathrm{~g} / \mathrm{d}(\mathbf{\square})$ or $212 \mathrm{~g} / \mathrm{d}(\mathbf{\Delta})$ of L-Gln dissolved in $10 \mathrm{~L}$ of saline.

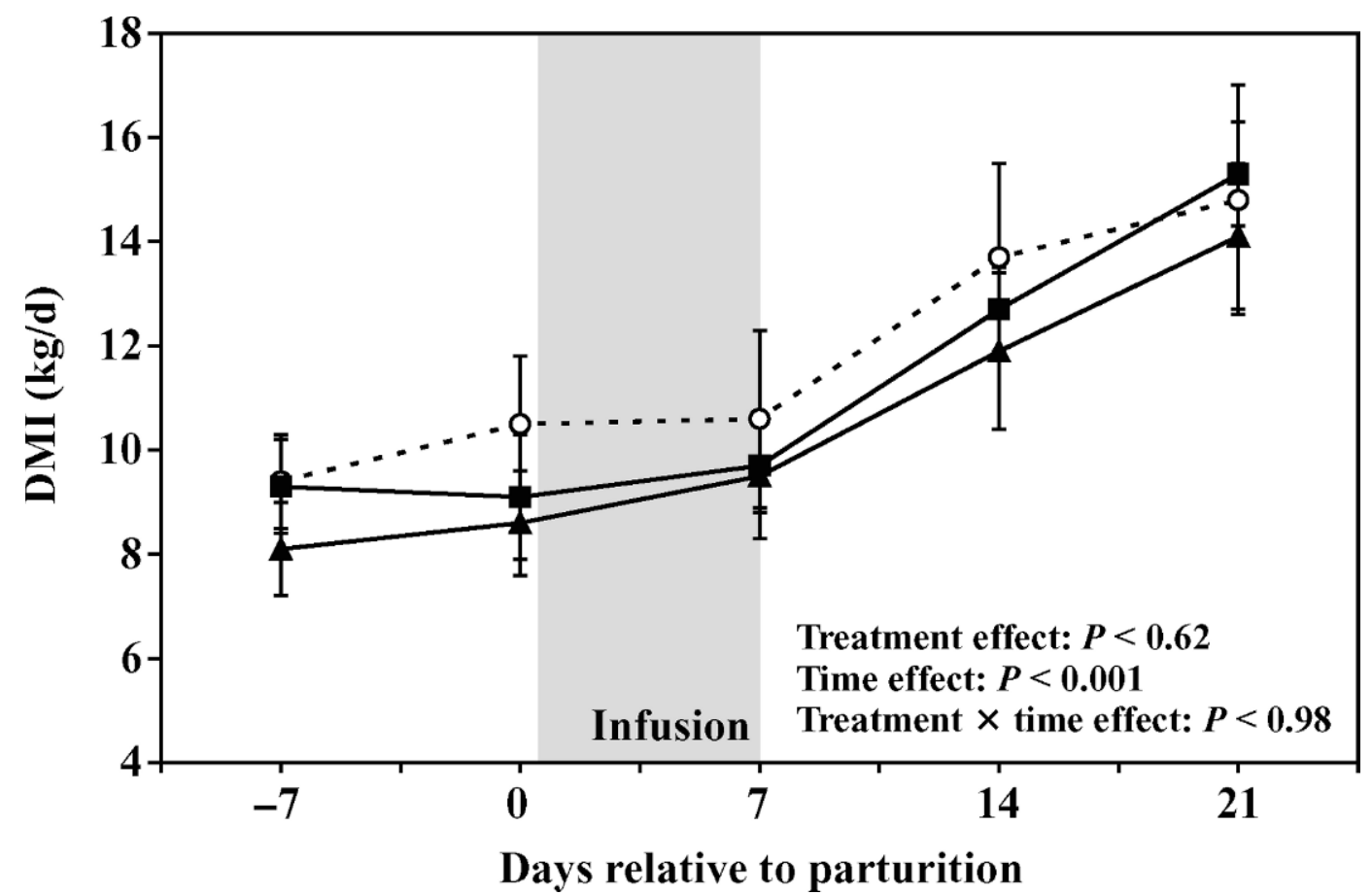

Figure 2. Least squares means $( \pm$ SEM) of DMI $(\mathrm{kg} / \mathrm{d})$ in Holstein dairy cows $(\mathrm{n}=8$ each group) infused i.v. for $8 \mathrm{~h}$ during $\mathrm{d} 1$ to 7 postpartum with either $10 \mathrm{~L}$ of saline $(0.85 \mathrm{~g} / \mathrm{L}$ of NaCl; control; $\mathrm{O})$ or $106 \mathrm{~g} / \mathrm{d}(\mathbf{\square})$ or $212 \mathrm{~g} / \mathrm{d}(\mathbf{\Lambda})$ of L-Gln dissolved in $10 \mathrm{~L}$ of saline. 


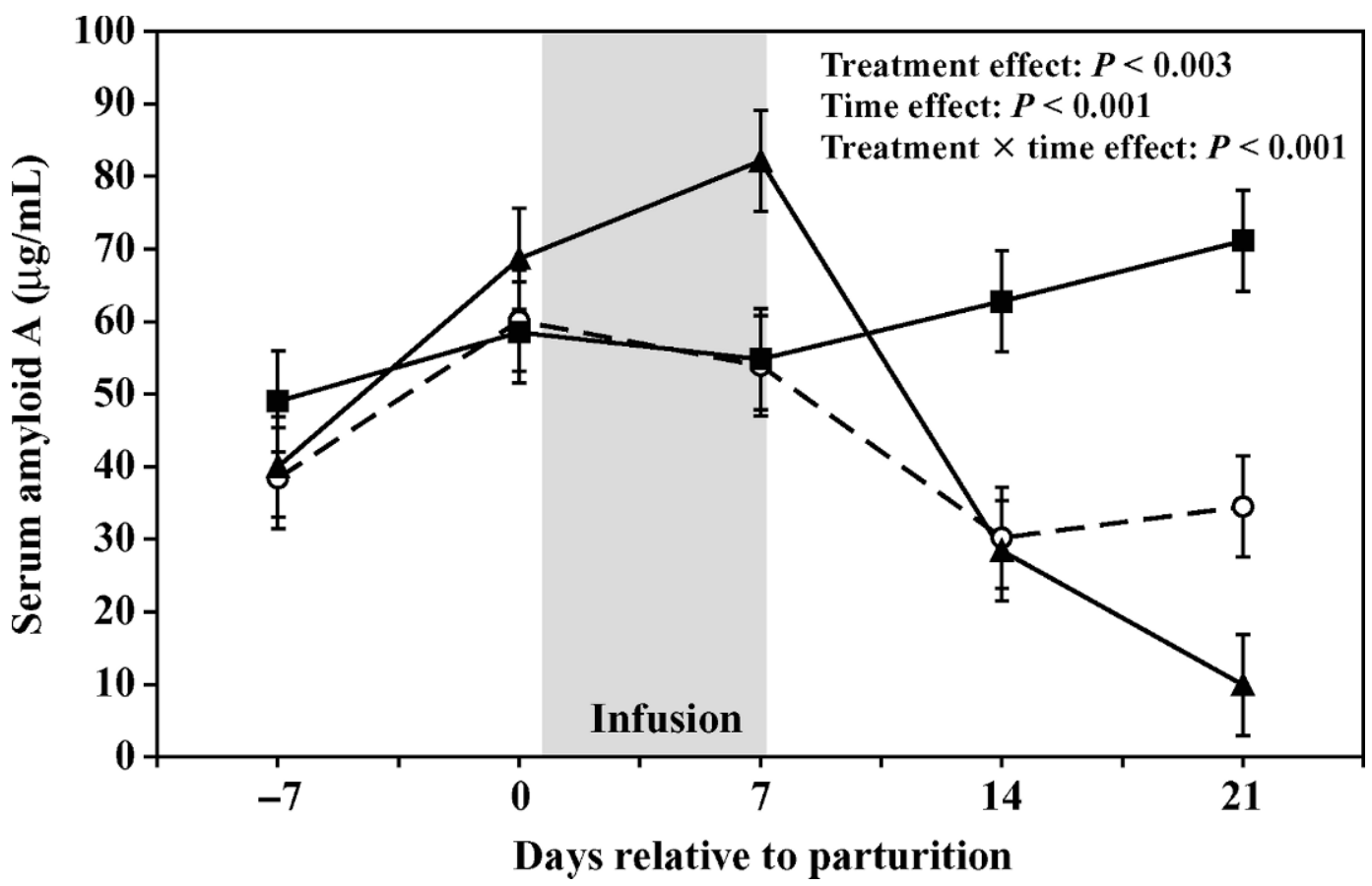

Figure 3. Least squares means $( \pm \mathrm{SEM})$ of serum amyloid A $(\mu \mathrm{g} / \mathrm{mL})$ measured in the plasma of Holstein dairy cows $(\mathrm{n}=8$ each group) infused i.v. for $8 \mathrm{~h}$ during d 1 to 7 postpartum with either $10 \mathrm{~L}$ of saline $(0.85 \mathrm{~g} / \mathrm{L}$ of NaCl; control; $\bigcirc)$ or $106 \mathrm{~g} / \mathrm{d}(\mathbf{\square})$ or $212 \mathrm{~g} / \mathrm{d}(\mathbf{\Delta})$ of LGln dissolved in $10 \mathrm{~L}$ of saline.

found for plasma concentrations of SAA (Figure 3). The concentrations of plasma SAA in control cows on d 0 increased above prepartal values $(\mathrm{d}-7 ; P<0.05)$ and then declined to precalving values $14 \mathrm{~d}$ after calving. Cows treated with $106 \mathrm{~g} / \mathrm{d}$ of L-Gln had greater concentrations of SAA in plasma at 14 and $21 \mathrm{~d}$ after parturition than did control cows $(P<0.001$ and $P<0.001$, respectively). In cows treated with $212 \mathrm{~g} / \mathrm{d}$ of L-Gln, plasma SAA concentrations increased on $\mathrm{d} 7$ compared with prepartal values $(P<0.01)$, decreased to lower than precalving values $21 \mathrm{~d}$ after parturition $(P=$ $0.002)$, and were lower than those of control cows 21 d postpartum $(P<0.01)$. Plasma SAA values differed between the $2 \mathrm{~L}-\mathrm{Gln}$ treated groups on $\mathrm{d} 7,14$, and 21 postpartum $(P<0.01, P<0.001$, and $P<0.001$, respectively).

A treatment and time effect were found for plasma concentrations of haptoglobin $(P<0.001$ and $P<0.001$, respectively; Figure 4). Concentrations of haptoglobin in the plasma of control cows and those treated with $106 \mathrm{~g} / \mathrm{d}$ of L-Gln were greater by d 7 compared with prepartum values ( $\mathrm{d}-7 ; P<0.01$ and $P<0.05$, respectively). Cows treated with $212 \mathrm{~g} / \mathrm{d}$ of L-Gln had lower concentrations of haptoglobin during d 14 and 21 postpartum compared with those of controls $(P<0.05$ and $P<0.05$, respectively) and with those treated with 106 g/d of L-Gln on d $14(P<0.05)$.
Treatment, time, and a treatment by time interaction were found for plasma concentrations of $\operatorname{LBP}(P<0.001$, $P<0.001$, and $P<0.001$, respectively; Figure 5). Plasma LBP for control cows was around $10 \mu \mathrm{g} / \mathrm{mL}$ during the entire 4 wk. In contrast, cows treated with $106 \mathrm{~g} / \mathrm{d}$ of L-Gln had greater overall LBP compared with controls and cows treated with $212 \mathrm{~g} / \mathrm{d}$ of L-Gln $(P<0.001$ and $P<0.001$, respectively). Differences among the cows treated with $106 \mathrm{~g} / \mathrm{d}$ of L-Gln and controls were obtained on $\mathrm{d} 7,14$, and 21 after parturition $(P<0.001, P<0.01$, and $P<0.01$, respectively). Cows treated with the lower dose of L-Gln had greater concentrations of LBP on d 7, 14, and 21 compared with cows treated with the larger dose of L-Gln $(P<0.001, P<0.001$, and $P<0.001$, respectively). Cows treated with $212 \mathrm{~g} / \mathrm{d}$ of L-Gln had greater plasma concentrations of LBP compared with controls $(P<0.05)$ at $7 \mathrm{~d}$ after parturition $(P<0.001)$.

Plasma $\alpha_{1}$-AGP increased more than 2 - to 3 -fold in all cows $7 \mathrm{~d}$ after parturition compared with prepartum values (d-7; time effect $P<0.001$; Figure 6 ). Moreover, there were no treatment or treatment by time effects for plasma $\alpha_{1}$-AGP $(P=0.09$ and $P=0.46$, respectively $)$.

\section{DISCUSSION}

The 2 doses of L-Gln (i.e., 106 and $212 \mathrm{~g} / \mathrm{d}$ ) correspond to 0.18 and $0.37 \mathrm{~g} / \mathrm{kg}$ per day, respectively. The higher 


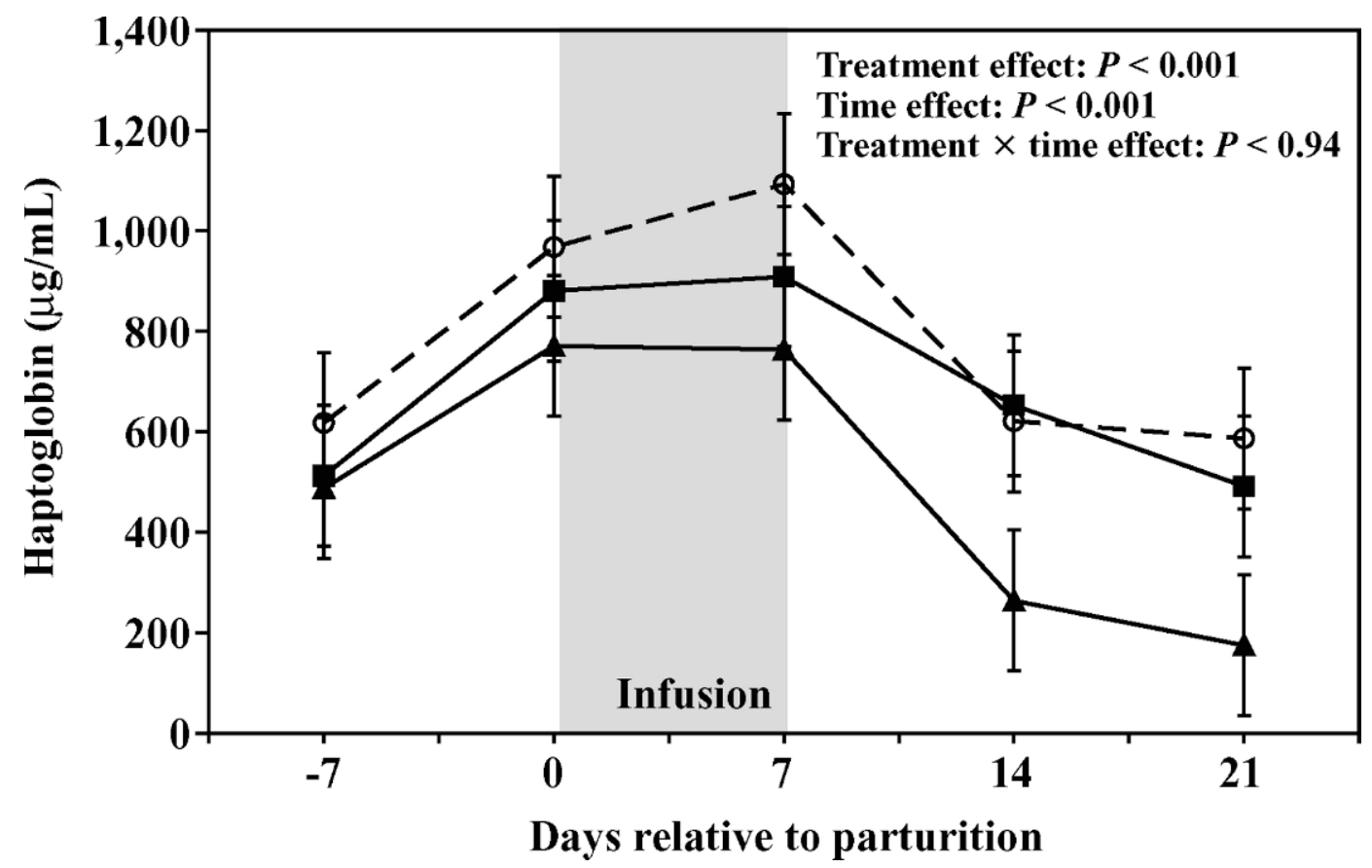

Figure 4. Least squares means $( \pm$ SEM) of plasma haptoglobin $(\mu \mathrm{g} / \mathrm{mL})$ measured in dairy cows $(\mathrm{n}=8$ each group) before and after i.v. infusion of either $10 \mathrm{~L}$ of saline $(0.85 \mathrm{~g} / \mathrm{L}$ of NaCl; control; $\mathrm{O})$ or $106 \mathrm{~g} / \mathrm{d}(\boldsymbol{\square})$ or $212 \mathrm{~g} / \mathrm{d}$ ( $\mathbf{\Delta})$ of L-Gln dissolved in $10 \mathrm{~L}$ of saline for $8 \mathrm{~h}$ during d 1 to 7 postpartum.

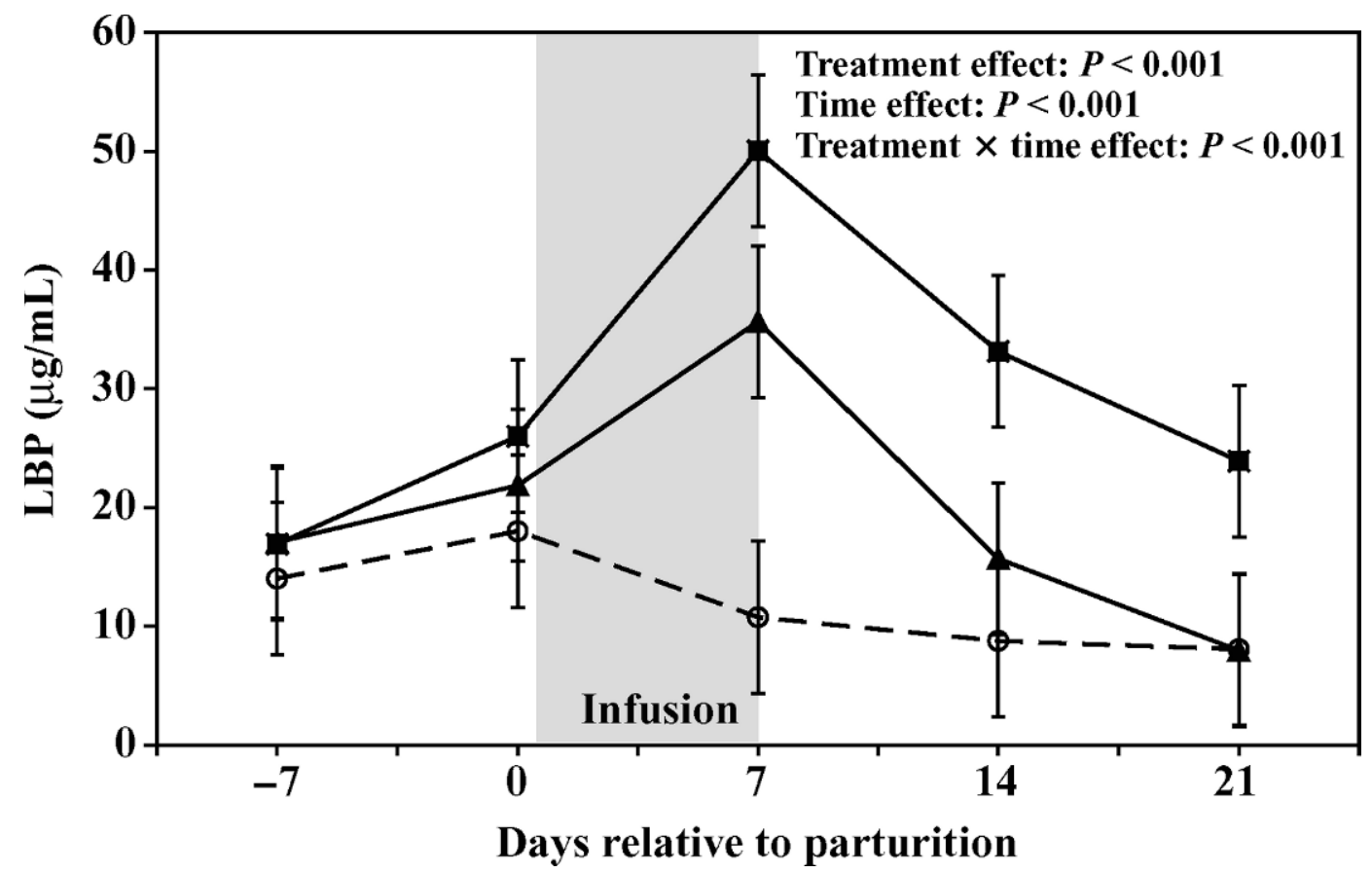

Figure 5. Least squares means $( \pm \mathrm{SEM})$ of plasma lipopolysaccharide-binding protein (LBP; $\mu \mathrm{g} / \mathrm{mL})$ measured in Holstein dairy cows $(\mathrm{n}=8$ each group) infused i.v. for $8 \mathrm{~h}$ during $\mathrm{d} 1$ to 7 postpartum with either $10 \mathrm{~L}$ of saline $(0.85 \mathrm{~g} / \mathrm{L}$ of $\mathrm{NaCl}$; control; $\bigcirc)$ or $106 \mathrm{~g} / \mathrm{d}(\mathbf{\square})$ or $212 \mathrm{~g} / \mathrm{d}(\boldsymbol{\Lambda})$ of L-Gln dissolved in $10 \mathrm{~L}$ of saline. 


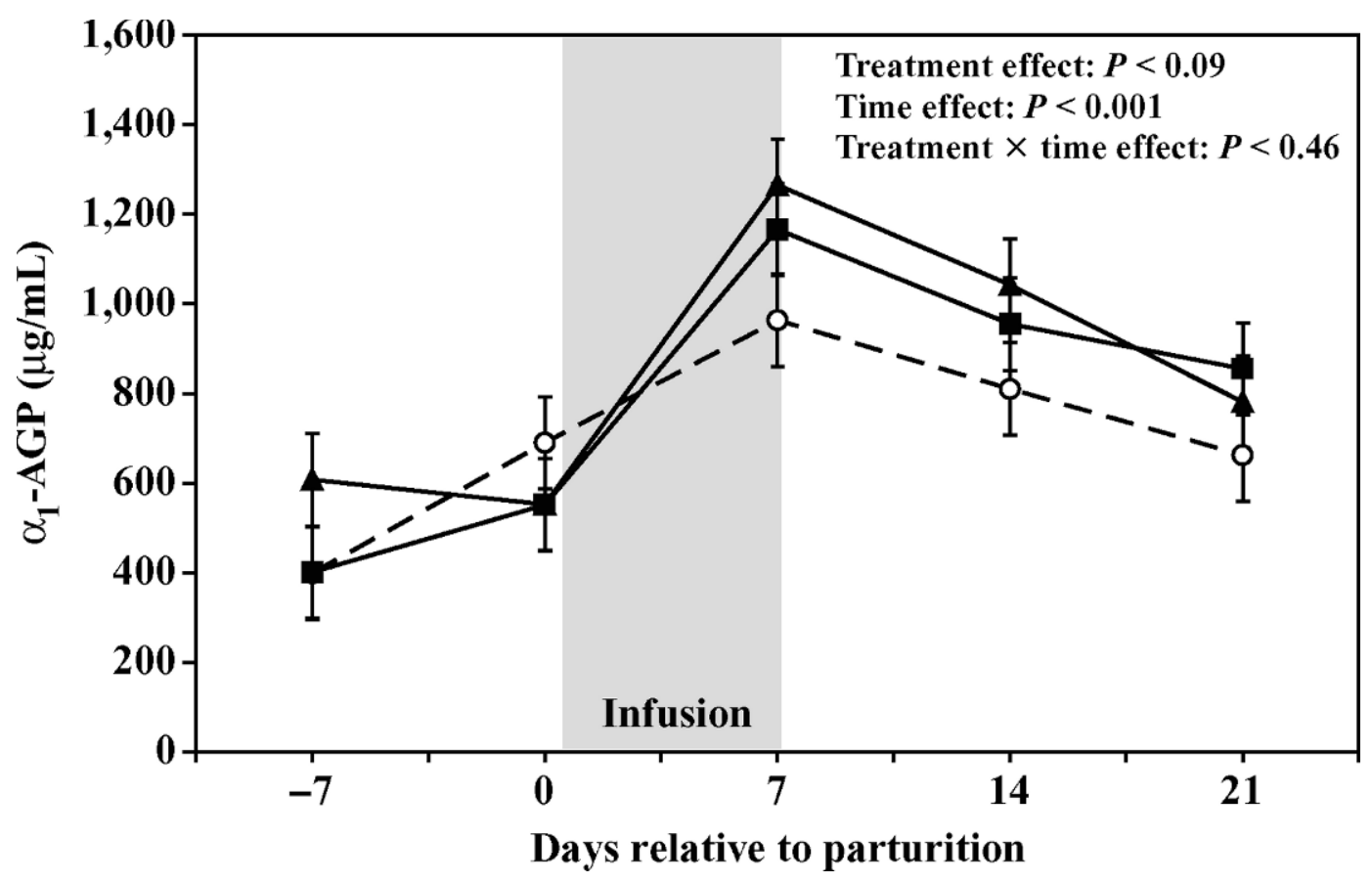

Figure 6. Least squares means $( \pm \mathrm{SEM})$ of plasma $\alpha_{1}$-acid glycoprotein $\left(\alpha_{1}\right.$-AGP; $\left.\mu \mathrm{g} / \mathrm{mL}\right)$ measured in Holstein dairy cows $(\mathrm{n}=8$ each group) infused i.v. for $8 \mathrm{~h}$ during d 1 to 7 postpartum with either $10 \mathrm{~L}$ of saline $(0.85 \mathrm{~g} / \mathrm{L}$ of NaCl; control; $\bigcirc)$ or $106 \mathrm{~g} / \mathrm{d}(\boldsymbol{\square})$ or $212 \mathrm{~g} / \mathrm{d}(\boldsymbol{\Delta})$ of L-Gln dissolved in $10 \mathrm{~L}$ of saline.

dose of L-Gln used in our experiment is 20 - to 58 -fold lower than the oral lethal doses of L-Gln for rats and mice $(7.5$ and $21.7 \mathrm{~g} / \mathrm{kg}$ of BW, respectively; Material Safety Data Sheet for L-Gln from Sigma Chemical Co., St. Louis, MO). We did not observe advantageous health effects of either dose of L-Gln used in our trial. Although there are no data on the pharmacological dose of L-Gln for ruminant animals, and assuming that the pharmacological dose for lactating cows might be quite different from those of humans and rodents, our data indicate no harmful effects of both the lower $(106 \mathrm{~g} / \mathrm{d})$ or the higher dose of L-Gln $(212 \mathrm{~g} / \mathrm{d})$ on health or productivity of transition dairy cows. No differences in milk yield, DMI, or health status were observed among the 3 groups of cows under investigation. Our data are consistent with previous research conducted in midlactation Holstein dairy cows showing that postruminal infusion of L-Gln at 100, 200, or $300 \mathrm{~g} / \mathrm{d}$ had no effect on DMI and milk yield (Plaizier et al., 2001).

An important finding of this study was that administration of both doses of L-Gln i.v. for 1 wk after parturition was associated with increased concentration of SAA in the plasma following the infusion in the group receiving $212 \mathrm{~g} / \mathrm{d}$ L-Gln, whereas the cows treated with $106 \mathrm{~g} / \mathrm{d}$ L-Gln showed an increase only 1 and $2 \mathrm{wk}$ after the infusion. The reason for the delayed increase in the concentrations of SAA in response to the lower dose of
L-Gln is unclear and remains to be elucidated in the future. An increase in the concentration of SAA also was observed in control cows during the first week after parturition. Presence of subacute inflammatory conditions might be the cause for increased SAA in the control cows. This is consistent with previous reports of increased concentrations of SAA in the plasma of transition dairy cows (Ametaj et al., 2005). Serum amyloid $\mathrm{A}$, an acute phase protein produced by the liver, is an apolipoprotein associated with HDL. This protein is present in small amounts under normal circumstances, but its concentration increases up to 1,000-fold in situations involving tissue injury or infection. Although there are no reports on the precise function of SAA, the protein is believed to substitute apolipoprotein A-1 in HDL during inflammatory conditions and to bind circulating endotoxin and rapidly remove endotoxin from circulation by the liver (Malle et al., 1993). Previous research indicates that feeding transition cows highgrain diets is associated with 20 -fold increase in the amount of endotoxin in the rumen and with translocation of endotoxin into the bloodstream (Andersen et al., 1994). Also, postpartum uterine and mammary gland infections are associated with translocation of endotoxin into the bloodstream (Mateus et al., 2003). Enhanced concentrations SAA in plasma by administration of L-Gln may help transition cows to clear translo- 
cated endotoxin during postpartum period. The mechanism by which L-Gln increases production of SAA is not well understood; however, it is speculated that L-Gln might be involved in production of SAA by hepatocytes.

Another important finding of this research is that cows treated with the higher dose of L-Gln $(212 \mathrm{~g} / \mathrm{d})$ had lower concentrations of haptoglobin during the 2 wk following the infusion. This suggests that L-Gln increased mucosal barrier functions or that L-Gln suppressed production of haptoglobin. Under normal conditions, haptoglobin is undetectable and becomes detectable only when bacteria are present in the bloodstream (Deignan et al., 2000). By binding to hemoglobin, haptoglobin prevents utilization of iron in the hemoglobin by bacteria (Wassell, 2000). Periparturient dairy cows are susceptible to infection and translocation of bacteria through mucosal barriers (mammary gland, uterus, and gastrointestinal tract) into the bloodstream because there is impaired neutrophil function and decreased immunoglobulin production during the periparturient period (Kehrli et al., 1989). Decreased concentration of plasma haptoglobin in cows treated with the higher dose of L-Gln $(212 \mathrm{~g} / \mathrm{d})$ suggests that L-Gln may have reduced translocation of bacteria into the bloodstream during the 2 wk following its administration. In support of this hypothesis is research conducted in other animals showing that administration of L-Gln improves maintenance of mucosal barrier functions, reduces translocation of bacteria, and increases killing of translocated bacteria and survival of treated animals (Domeneghini et al., 2006). On the other hand, it is possible that L-Gln suppressed production of haptoglobin by hepatocytes. The mechanism by which L-Gln suppresses production of haptoglobin remains to be elucidated in the future.

We show that cows treated with L-Gln had higher plasma concentrations of LBP. Increasing evidence suggests a protective role for LBP in mediating the host response to endotoxin and gram-negative infections. Research indicates that administration of LBP protected mice from septic shock induced by LPS or Escherichia coli infection (Lamping et al., 1998). Lipopolysaccharide-binding protein performs 2 main functions: 1) it enhances transfer of endotoxin to the CD14-TLR4 receptor complex on macrophages, and 2) it facilitates transfer and neutralization of endotoxin by lipoproteins (Wurfel et al., 1995). Enhanced concentrations of LBP by administration of L-Gln may help in expediting removal of endotoxin from the circulation. The higher concentrations of plasma LBP with respect to the lower dose $(106 \mathrm{~g} / \mathrm{d})$ of L-Gln were unexpected; however, we speculate that this may be due to an optimal concentration of L-Gln for LBP synthesis in hepatocytes.
Although i.v. infusion of 2 doses of L-Gln had no effect on plasma $\alpha_{1}$-AGP, concentrations of $\alpha_{1}$-AGP increased in all cows at $7 \mathrm{~d}$ after parturition. The $\alpha_{1}$-AGP is an acute phase protein produced mainly in the liver (Sarcione, 1967). Like most acute phase proteins, $\alpha_{1}$-AGP is induced by cytokines, and IL-1 and IL- 6 are powerful inducers of $\alpha_{1}$-AGP both in vitro and in vivo (Baumann and Gauldie, 1994). There is an inflammatory condition associated with the transition period in dairy cows evidenced by greater concentrations of acute phase proteins and cytokines such as IL-6 and tumor necrosis factor- $\alpha$ in the plasma (Ametaj et al., 2005). Although the precise biological function of $\alpha_{1}$-AGP is not well understood, most investigations suggest an anti-inflammatory role of $\alpha_{1}$-AGP as indicated by inhibition of platelet aggregation (Costello et al., 1979), neutrophil activation (Bennett and Schmid, 1980), and proliferation of peripheral blood lymphocytes in response to phytohemagglutinin (Chiu et al., 1977). On the other hand, $\alpha_{1}$-AGP protects against tumor necrosis factor-induced lethal shock and hepatitis (Libert et al., 1991). Increased concentration of $\alpha_{1}$-AGP in all cows may be due to presence of subacute inflammatory conditions postpartum and the host response to control the inappropriate and extended immune responses.

\section{CONCLUSIONS}

In summary, i.v. administration of 106 or $212 \mathrm{~g} / \mathrm{d}$ of L-Gln per day for 7 consecutive days immediately after parturition modulated the acute phase response in postparturient dairy cows. Infusion of L-Gln into the blood of postpartum cows was associated with increased concentrations of SAA and LBP and decreased concentrations of haptoglobin in the plasma of cows indicating a role for L-Gln in production of acute phase proteins and maintenance of mucosal barrier functions. The mechanism by which L-Gln affected plasma concentration of acute phase proteins remains to be elucidated in the future; however, it is suggested that L-Gln may exert its effects by enhancing production of cytokines by cells of the immune system or by improving maintenance of gut barrier functions. Further research also is warranted to investigate whether oral L-Gln would produce similar immunomodulatory effects on transition dairy cows.

\section{ACKNOWLEDGMENTS}

The authors thank Ajinomoto Co., Inc. (Tokyo, Japan) for donation of L-Gln and are grateful to the staff of Dairy Research and Technology Centre at University of Alberta for their continuous technical help and support. We also thank Laki Goonewardene for statistical advice 
and acknowledge the financial support of the University of Alberta, Natural Sciences and Engineering Council of Canada, Alberta Milk, and Dairy Farmers of Canada.

\section{REFERENCES}

Ametaj, B. N., B. J. Bradford, G. Bobe, R. A. Nafikov, Y. Lu, J. W. Young, and D. C. Beitz. 2005. Strong relationships between mediators of the acute phase response and fatty liver in dairy cows. Can. J. Anim. Sci. 85:165-175.

Andersen, P. H., B. Bergelin, and K. A. Christensen. 1994. Effect of feeding regimen on concentration of free endotoxin in ruminal fluid of cattle. J. Anim. Sci. 72:487-491.

Baumann, H., and J. Gauldie. 1994. The acute phase response. Immunol. Today 15:74-80.

Baumberger, C., R. J. Ulevitch, and J. M. Dayer. 1991. Modulation of endotoxic activity of lipopolysaccharide by high-density lipoprotein. Pathobiology 59:378-383.

Bennett, M., and K. Schmid. 1980. Immunosuppression by human plasma alpha 1-acid glycoprotein: Importance of the carbohydrate moiety. Proc. Natl. Acad. Sci. USA 77:6109-6113.

Bequette, B. J., J. A. Metcalf, D. Wray-Cahen, F. R. C. Backwell, J. D. Sutton, M. A. Lomax, J. C. MacRae, and G. E. Lobley. 1996. Leucine and protein metabolism in the lactating dairy cow mammary gland: Responses to supplemental dietary crude protein intake. J. Dairy Res. 63:209-222.

Canadian Council on Animal Care. 1993. Guide to the Care and Use of Experimental Animals. Vol. 1, 2nd ed. E. D. Olfert, B. M. Cross, and A. A. McWilliam, ed. CCAC, Ottawa, Ontario, Canada.

Chiu, K. M., R. F. Mortensen, A. P. Osmand, and H. Gewurz. 1977. Interactions of alpha 1-acid glycoprotein with the immune system. I. Purification and effects upon lymphocyte responsiveness. Immunology 32:997-1005.

Costello, M., B. A. Fiedel, and H. Gewurz. 1979. Inhibition of platelet aggregation by native and desialised alpha 1-acid glycoprotein. Nature 281:677-678.

Deignan, T., A. Alvan, J. Kelly, J. McNair, T. Warren, and C. O'Farrelly. 2000. Serum haptoglobin: An objective indicator of experimentally induced Salmonella infection in calves. Res. Vet. Sci. 69:153-158.

Domeneghini, C., A. Di Giancamillo, G. Bosi, and S. Arrighi. 2006. Can nutraceuticals affect the structure of intestinal mucosa? Qualitative and quantitative microanatomy in L-glutamine dietsupplemented weaning piglets. Vet. Res. Commun. 30:331-342.

Godson, D. L., M. Campos, S. K. Attah-Poku, M. J. Redmond, D. M. Cordeiro, M. S. Sethi, R. J. Harland, and L. A. Babiuk. 1996. Serum haptoglobin as an indicator of the acute phase response in bovine respiratory disease. Vet. Immunol. Immunopathol. 51:277-292.

Hoskin, S. O., S. Gavet, E. Milne, and G. E. Lobley. 2001. Does glutamine act as a substrate for transamination reactions in the liver of fed and fasted sheep? Br. J. Nutr. 85:591-597.
Kehrli, M. E., Jr., B. J. Nonnecke, and J. A. Roth. 1989. Alterations in bovine neutrophil function during the periparturient period. Am. J. Vet. Res. 50:207-214.

Lamping, N., R. Dettmer, N. W. J. Schröder, D. Pfeil, W. Hallatschek, R. Burger, and R. R. Schumann. 1998. LPS-binding protein protects mice from septic shock caused by LPS or Gram-negative bacteria. J. Clin. Invest. 101:2065-2071.

Libert, C., S. Van Bladel, P. Brouckaert, A. Shaw, and W. Fiers. 1991. Involvement of the liver, but not of IL-6, in IL-1-induced desensitization to the lethal effects of tumor necrosis factor. J. Immunol. 146:2625-2632.

Malle, E., A. Steinmetz, and J. G. Raynes. 1993. Serum amyloid A (SAA): An acute phase protein and apolipoprotein. Atherosclerosis 102:131-146.

Mancini, G., A. O. Carbonara, and J. F. Heremans. 1965. Immunochemical quantitation of antigens by single radial immunodiffusion. Immunochemistry 2:235-254.

Mateus, L., L. Lopes da Costa, P. Diniz, and A. J. Ziecik. 2003. Relationship between endotoxin and prostaglandin (PGE2 and PGFM) concentrations and ovarian function in dairy cows with puerperal endometritis. Anim. Reprod. Sci. 76:143-154.

Meijer, G. A., J. Van der Meulen, and A. M. Van Vuuren. 1993. Glutamine is a potentially limiting amino acid for milk production in dairy cows: A hypothesis. Metabolism 42:358-364.

Moore, D. F., M. R. Rosenfeld, P. M. Gribbon, C. P. Winlove, and C. M. Tsai. 1997. Alpha-1-acid (AAG, orosomucoid) glycoprotein: Interaction with bacterial lipopolysaccharide and protection from sepsis. Inflammation 21:69-82.

National Research Council. 2001. Nutrient Requirements of Dairy Cattle. 7th rev. ed. Natl. Acad. Sci., Washington, DC.

Palmer, T. E., R. D. Griffiths, and C. Jones. 1996. Effect of parenteral L-glutamine on muscle in the very severely ill. Nutrition 12:316-320.

Plaizier, J. C., J. P. Walton, and B. W. McBride. 2001. Effect of postruminal infusion of glutamine on plasma amino acids, milk yield, and composition in transition dairy cows. Can. J. Anim. Sci. 81:229-235.

Plumley, D. A., W. W. Souba, R. D. Hautamaki, T. D. Martin, T. C. Flynn, W. R. Rout, and E. M. Copeland. 1990. Accelerated lung amino acid release in hyperdynamic septic surgical patients. Arch. Surg. 125:57-61.

Sarcione, E. J. 1967. Hepatic synthesis and secretory release of plasma alpha-2 (acute phase)-globulin appearing in malignancy. Cancer Res. 27:2025-2033.

SAS Institute. 2002. SAS/STAT User's Guide. Version 9.1. SAS Institute Inc., Cary, NC.

Wang, Z., and L. A. Goonewardene. 2004. The use of MIXED models in the analysis of animal experiments with repeated measures data. Can. J. Anim. Sci. 84:1-11.

Wassell, J. 2000. Haptoglobin: Function and polymorphism. Clin. Lab. 46:547-552.

Wurfel, M. M., E. Hailman, and S. D. Wright. 1995. Soluble CD14 acts as a shuttle in the neutralization of lipopolysaccharide (LPS) by LPS binding protein and reconstituted high density lipoprotein. J. Exp. Med. 181:1743-1754. 